\title{
Mural granulosa cell gene expression associated with oocyte developmental competence
}

\author{
Jin-Yi Jiang ${ }^{1}$, Huiling Xiong ${ }^{2}$, Mingju Cao ${ }^{1}$, Xuhua Xia ${ }^{2}$, Marc-Andre Sirard ${ }^{3}$, Benjamin K Tsang ${ }^{1,4^{*}}$
}

\begin{abstract}
Background: Ovarian follicle development is a complex process. Paracrine interactions between somatic and germ cells are critical for normal follicular development and oocyte maturation. Studies have suggested that the health and function of the granulosa and cumulus cells may be reflective of the health status of the enclosed oocyte. The objective of the present study is to assess, using an in vivo immature rat model, gene expression profile in granulosa cells, which may be linked to the developmental competence of the oocyte. We hypothesized that expression of specific genes in granulosa cells may be correlated with the developmental competence of the oocyte.
\end{abstract}

Methods: Immature rats were injected with eCG and $24 \mathrm{~h}$ thereafter with anti-eCG antibody to induce follicular atresia or with pre-immune serum to stimulate follicle development. A high percentage (30-50\%, normal developmental competence, NDC) of oocytes from eCG/pre-immune serum group developed to term after embryo transfer compared to those from eCG/anti-eCG (0\%, poor developmental competence, PDC). Gene expression profiles of mural granulosa cells from the above oocyte-collected follicles were assessed by Affymetrix rat whole genome array.

Results: The result showed that twelve genes were up-regulated, while one gene was down-regulated more than 1.5 folds in the NDC group compared with those in the PDC group. Gene ontology classification showed that the up-regulated genes included lysyl oxidase (Lox) and nerve growth factor receptor associated protein 1 (Ngfrap 1), which are important in the regulation of protein-lysine 6-oxidase activity, and in apoptosis induction, respectively. The down-regulated genes included glycoprotein-4-beta galactosyltransferase 2 (Ggbt2), which is involved in the regulation of extracellular matrix organization and biogenesis.

Conclusions: The data in the present study demonstrate a close association between specific gene expression in mural granulosa cells and the developmental competence of oocytes. This finding suggests that the most differentially expressed gene, lysyl oxidase, may be a candidate biomarker of oocyte health and useful for the selection of good quality oocytes for assisted reproduction.

\section{Introduction}

Ovarian follicle development is a complex process. Paracrine interactions between somatic and germ cells are critical for normal follicular development [1]. Defects in meiotic maturation have been observed in mice lacking the granulosa cell oocyte junction protein connexin 37 [2], and somatic cells in ovaries are known to participate in regulating oocyte growth and development $[3,4]$, meiosis [5], and global transcriptional activity [6,7]. On the other

\footnotetext{
* Correspondence: btsang@ohri.ca

'Department of Obstetrics \& Gynecology and Cellular \& Molecular Medicine, University of Ottawa, Ottawa Hospital Research Institute, Ottawa, ON K1Y 4E9, Canada

hand, oocytes also promote granulosa cell proliferation and differentiation [1]. It has been shown that mouse oocytes promote granulosa cell proliferation in preantral and antral follicles in vitro [8] and that cumulus expansion and granulosa cell differentiation are dependent upon oocyte-derived factors $[9,10]$. In rodents, oocyte-secreted GDF-9 and BMP15 promote proliferation of granulosa cells from small antral follicles, and BMP15 inhibits FSHstimulated progesterone production [11]. Evidence also indicates that while GDF9 suppresses expression of both KitL-1 and KitL-2 in granulosa cells from rat early antral follicles, KitL-1 expression can be promoted by BMP15 in vitro [4]. In addition, we have recently shown that GDF-9 
from the oocyte promotes pre-antral follicles development by up-regulating granulosa cell FSH receptor mRNA expression and preventing granulosa cell apoptosis via activation of the phosphatidylinositol 3-kinase/Akt pathway [12]. Thus, while oocyte maturation is known to depend on secretory products of the granulosa and cumulus cells, proliferation, differentiation and apoptosis of these support cells is also under tight control of the oocyte, suggesting that the health and function of the granulosa and cumulus cells may be reflective of the health status of the enclosed oocyte.

The quality of the oocyte is largely dependent on its follicular environment, as shown in a number of animal and human studies $[4,13]$. During ovarian stimulation and ovulation induction, a cohort of heterogeneous follicles is recruited to develop and ovulate, irrespective of their differentiative state. This creates an asynchrony in the maturation process and heterogeneity in the quality of the oocytes recovered for assisted reproduction. The morphological appearance, which is widely used as the primary criterion for oocyte selection in the human fertility clinic, does not accurately predict the health of the oocyte [14]. In fact, only a small proportion of the oocyte population can develop to healthy embryos after fertilization and healthy fetuses after transfer.

Although multiple factors are at play in determining pregnancy outcome in assisted reproduction including age, sperm quality (male factor), fertilization capacity and number of embryos transferred, the effect of fertilization rate appears to be of less significance [15] and that intrinsic deficiencies of the oocyte and/or embryo account for greater than $50 \%$ of failed conceptions [16]. These findings suggest that the developmental competence of the oocytes is a major determinant in the establishment of successful pregnancy in assisted reproduction.

Two factors contributing to oocyte health are chromosomal constitution and gene expression patterns of the oocyte and the follicular micro-environment in which the oocyte grows and matures. It has been shown that eCG stimulates follicular development and oocyte maturation in immature rats [17]. After hCG treatment, superovulated oocytes in eCG-primed immature rats can be fertilized in vitro and developed to term after embryo transfer [18]. In addition, our model also indicates that eCG/hCG treatment resulted in decreased estradiol level at the time of oocyte collection, as also been reported in the bovine dominant preovulatory follicles [19]. This model is physiologically relevant since it is well established that high level of LH (e.g. LH surge) during preovulatory development is associated with marked decrease in follicular and circulatory estradiol levels and that insufficient gonadotropin support results in atresia of the subordinate follicles. In the latter context, withdrawal of gonadotropic support (e.g. anti-eCG antibody treatment) in the present model induced granulosa cell apoptosis and follicular atresia [20-22]. Fertilization and developmental competence of oocytes from anti-eCG treated rats are dependent on the dilution of antibody used (Jiang et al., unpublished data).

The objective of the present study is to assess, using an in vivo immature rat model, gene expression profile in granulosa cells, which may be linked to the developmental competence of the oocyte. We hypothesized that expression of specific genes in granulosa cells may be correlated with the developmental competence of the oocyte. These findings will facilitate future investigation on the identification of non-invasive biomarkers indicative of oocyte health status which would allow one to select only good-quality oocytes for in vitro fertilization (IVF) and intracytoplasmic sperm injection (ICSI) and to transfer fewer embryos for successful pregnancy.

\section{Materials and methods \\ Materials}

All reagents were purchased from Sigma Chemical Company (St. Louis, MO) unless otherwise stated.

\section{Animal care}

Sprague-Dawley rats and New Zealand White Rabbits were purchased from Charles River Canada (Montreal, $\mathrm{PQ}$, Canada). Rats were kept in polycarbonated cages with wood shavings on the floor at $21^{\circ} \mathrm{C}, 50 \%$ humidity and a light/dark cycle at 7:00 h/19:00 h. They were given bullet type commercial rat feed and tap water ad libitum. The studies were carried out in accordance to the Guide to Care and Use of Experimental Animals of the Canadian Council on Animal Care and approved by the Animal Care Committee of the Ottawa Health Research Institute.

\section{Production of anti-eCG antiserum}

Three male rabbits (2.5 - 3.0 Kg body weight [BW]) were used to produce anti-eCG antisera as described previously [21]. Antibody titres were determined by ELISA. In the bioassay for the antiserum, immature female rats injected with $10 \mathrm{IU}$ eCG were injected $24 \mathrm{~h}$ later with highest-titre antiserum or pre-immune serum (100 ul of 1:5 to 1:200 dilution in PBS, i.p.). The ovaries were removed $24 \mathrm{~h}$ after treatment and weighed, the ability of various concentrations of the antiserum to prevent eCGinduced ovarian weight gain was assessed. The above dilution (1:5 to 1:200 dilution) of anti-eCG serum significantly decreased ovarian weight in eCG-primed rats.

\section{Animal treatment and collection of oocytes and mural granulosa cells}

Eight immature rats were injected with eCG (10 IU; s.c.; G4877) and $24 \mathrm{~h}$ thereafter with either pre-immune 
serum (control; to stimulate follicle development) or anti-eCG antibody (1:400, to induce follicular atresia). Twenty-four hours later, hCG (10 IU; i.p.; CG-5) was administered. Cumulus-oocyte complexes (COCs) and mural granulosa cells collected by follicle puncture $13 \mathrm{~h}$ after hCG were respectively subjected to in vitro fertilization or kept at $-80^{\circ} \mathrm{C}$ until the assessment of gene expression, as described hereafter.

\section{In vitro fertilization (IVF) and embryo transfer}

To assess the developmental competence of oocytes which were morphologically indistinguishable in both groups, COCs were inseminated in vitro and the fertilized oocytes were transferred into pseudo-pregnant rats as described previously [23]. Briefly, sperm suspensions $\left(1 \times 10^{6}\right.$ cells $\left./ \mathrm{ml}\right)$ were pre-incubated in insemination media $(400 \mu \mathrm{l}$ of IVF-30 supplemented with $30 \mathrm{mM}$ $\mathrm{NaCl})$ for 5 to $7 \mathrm{~h}$ at $37^{\circ} \mathrm{C}$ in $5 \% \mathrm{CO}_{2}$ in air. COCs were then carefully transferred into the suspension drops and incubated for $12 \mathrm{~h}$. The oocytes were transferred into $100 \mu \mathrm{l}$ of culture medium and freed from surrounding cumulus cells. The denuded oocytes were considered fertilized if they exhibited the presence of pronuclei with sperm tail(s) in the vitellus.

To assess the developmental competence in vivo of embryos fertilized in vitro, nine to ten embryos at the 1cell stage were transferred to the oviducts of each pseudo-pregnant recipient at Day 1. Vaginal smear of recipients was examined on days 1 and 4 as well as days 12-14 after transfer to confirm successful induction of pseudo-pregnancy and signs of pregnancy, respectively. All recipients were sacrificed by day 24 of pregnancy regardless of delivering offspring, and their uterine horns were examined for implantation sites. The number of young was counted on the day of parturition.

\section{RNA isolation}

Total RNAs from mural granulosa cells collected from ovarian follicles were extracted using RNeasy Mini kit according to manufacturer's instructions and DNA contamination was removed by DNase I digestion (Qiagen Inc., Mississauga, ON, Canada). All total RNA specimens were quantified and checked for quality with a Bioanalyzer 2100 system (Agilent, Palo Alto, CA) before further manipulation.

\section{Affymetrix GeneChip hybridization and image acquisition} A total of 4 NDC and 4 PDC samples were used, thus requiring a total of 8 GeneChips. The GeneChip hybridization and image acquisition were performed at the Ontario Genome Center. Briefly, two rounds of amplification were carried out to successfully generate sufficient labeled cRNA for microarray analysis from $100 \mathrm{ng}$ of total RNA. For first round synthesis of double- stranded cDNA, total RNA was reverse transcribed using the Two-Cycle cDNA Synthesis kit (Affymetrix) and oligo (dT) 24-T7 (5'-GGCCAGTGAATTGTAATACGACTCACTATAGGGAGGCGG-3') primer followed by amplification with the MEGAscript T7 kit (Ambion, Inc., Austin, TX). After cleanup of the cRNA with a GeneChip Sample Cleanup Module IVT Column (Affymetrix), a second-round double-stranded cDNA was produced using the IVT Labeling kit (Affymetrix). A $15 \mu$ g-aliquot of labeled product was fragmented by heat and ion-mediated hydrolysis $\left(94^{\circ} \mathrm{C}, 35\right.$ minutes) in $24 \mu \mathrm{L} \mathrm{H}_{2} \mathrm{O}$ and $6 \mu \mathrm{L}$ of $5 \times$ fragmentation buffer (Affymetrix). The fragmented cRNA was made into hybridization cocktail and was hybridized $\left(16 \mathrm{~h}, 45^{\circ} \mathrm{C}\right)$ to an Affymetrix Rat 230.2 array. Washing and staining of the arrays with phycoerythrin-conjugated streptavidin (Molecular Probes, Eugene, OR) was completed in a Fluidics Station 450 (Affymetrix). The arrays were then scanned using a confocal laser GeneChip Scanner 3000 and GeneChip Operating Software (Affymetrix).

\section{Microarray data analysis}

Gene expression patterns were determined using Affymetrix Genechip Arrays Rat 230.2. Prior to any statistical analysis, raw data were normalized and compared using RMA (robust multichip average) method from the BioConductor package http://www.bioconductor.org, which uses a robust average of $\log _{2}$-transformed background-corrected perfect match probe signal intensities combined with a quantile normalization method $[24,25]$. The quality analysis of the slides was performed by checking the logarithmic scatter plots of probe set intensities in all the non-redundant pairs of replicated samples after the normalization procedure [26]. Normalized data were then filtered in three steps. First, probe sets called 'Absent' (A) over all conditions and replicates across the complete dataset were excluded. Second, a threshold as the $95^{\text {th }}$ percentile of all the absent call signals of the entire dataset was set. All the remaining probe sets whose expression values were consistently below this value were removed in each sample [26]. To extract significant genes between two independent groups, the two-sample $t$ statistic was used for filtered genes. In addition, multiple testing corrections were performed by computing adjusted p values using the Bonferroni and Sidak algorithm which provides experimentwise (or Family-wise) type I control. Genes with a fold change of 1.2 (increase or decrease) relative to the poor oocyte developmental competence were subsequently used. Hierarchical clustering of samples and gene expression values based on similarities of expression levels was performed using the average linkage method and Euclidean distance measurements as implemented in the TIGR Multiexperiment Viewer (MeV) program 
[27]. Gene Ontology (GO) analysis was performed with DAVID http://david.abcc.ncifcrf.gov/[28].

Reproducibility between experiments was assessed by calculating the pairwise concordance of presence calls, which was $92.1-97.9 \%$, and by computing the pairwise Adjusted Coefficient of Determination of log-transformed signal intensities (average of 0.952). High correlation of array signals (low intra-experimental group variation) was observed between rat samples within the groups with oocytes showing normal and poor developmental competence (Data not shown).

\section{Quantitative real-time PCR validation of microarray results}

In order to validate the results of microarray, real time RT-PCR analysis was performed on all 8 samples. Briefly, $0.4 \mu \mathrm{g}$ of total RNAs extracted from mural granulosa cells of each rat ovarian follicles were reverse transcribed in a final volume of $40 \mu \mathrm{l}$ solution containing First-Strand Buffer, dNTPs, dithiothreitol (DTT), RevertAid Enzyme (Fermentas), and Random Decamer Primers (Ambion, Inc.). Ten representative genes whose expression levels were remarkably changed in microarray (see Table 1) were further validated, they are lysyl oxidase (Lox), glycoprotein-4-beta-galactosyltransferase 2 (Ggbt2; UDP-Gal), nerve growth factor receptor associated protein 1 (Ngfrap1), protein disulfide isomeraseassociated 5 and 6 (Pdia5 and Pdia6), myeloid ecotropic viral integration site 1 homolog (Meis1), CD83 antigen, lysozyme (Lyz), trinucleotide repeat containing 6 (Tnrc6), interleukin 13 receptor alpha 1 (Il13ra1). Realtime quantitative PCR analyses for those genes were performed using a LightCycler 2.0 System (Roche Diagnostic Corporation) and a QuantiTect SYBR Green PCR kit (Qiagen, Mississauga, ON, Canada). The thermal cycling conditions were comprised of an initial denaturation step at $95^{\circ} \mathrm{C}(15 \mathrm{~min})$ and 40 cycles at $95^{\circ} \mathrm{C}(15$ $\mathrm{sec}), 58^{\circ} \mathrm{C}(20 \mathrm{sec})$ and $72^{\circ} \mathrm{C}(30 \mathrm{sec})$. The primer sequence for each gene, their PCR product size, primer location on rat chromosome, and GeneBank access numbers were shown in Table $1.18 \mathrm{~S}$ ribosomal RNA was used as control. Target gene expression level was calculated by relative expression ratio (RER) of Normal Developmental Competence (NDC) to Poor Developmental Competence (PDC), all normalized by $18 \mathrm{~S}$ as described previously [29]. Briefly, the Livak Method ( $2^{-\Delta \Delta C t}$ method) was performed by the following formula: 1) Calculate crossing point change of NDC relative to housekeeping gene $18 \mathrm{~S}, \Delta \mathrm{Ct}(\mathrm{NDC})=\mathrm{Ct}$ (target gene, NDC)-Ct (18S, NDC); 2) Calculate crossing point change of PDC relative to housekeeping gene $18 \mathrm{~S}, \Delta \mathrm{Ct}$ $(\mathrm{PDC})=\mathrm{Ct}$ (target gene PDC) - Ct(18S, PDC); 3) Calculate the difference of these changes between NDC and PDC group, $\Delta \Delta \mathrm{Ct}=\Delta \mathrm{Ct}(\mathrm{NDC})-\Delta \mathrm{Ct}(\mathrm{PDC}) ; 4)$ finally calculate $\mathrm{RER}=2^{-\Delta \Delta \mathrm{Ct}}$. Fold changes by real-time $\mathrm{qPCR}$ in Table 1 were calculated by Mean of RER for NDC over PDC.

\section{Statistical Analysis}

Data in Table 2 and real-time PCR results (Fig. 1) were analyzed by student's t-test tests using Graph Pad Prism 3 software. Differences with $\mathrm{P}<0.05$ were considered statistically significant.

\section{Results}

Production of oocytes with poor and normal developmental competence

Treatment of eCG-primed rats with low dose of antieCG antiserum (1:400 dilution) failed to significantly decrease paired ovarian weight $(108.2 \pm 7.9 \mathrm{mg}$ versus $93.3 \pm 4.7 \mathrm{mg} ; \mathrm{P}>0.05)$ and fertilization rates $(93.5 \pm$ $2.7 \%$ versus $95.8 \pm 2.2 \%, \mathrm{P}>0.05$ ) when compared with those in eCG plus pre-immune serum-treated group (Table 2). However, anti-eCG antiserum injection resulted in the production of oocytes with poor developmental competence. No embryos in this group could develop to term after embryo transfer. In contrast, as high as $30 \%-50 \%$ of oocytes from eCG-primed rats developed to offspring ( $\mathrm{P}<0.05)$. No significant differences in the number of implantation sites were observed between two groups (Table 2).

Microarray identification of differentially expressed genes The global gene expression profiles in rat granulosa cell samples representing oocytes of poor and normal developmental competence were identified with microarray technique. Results in Fig. 2 (left panel) show that among the approximately 30,000 genes queried on Rat 230.2 array, there were more undetected genes than detected genes observed in all arrays. Mean expression intensities of detected genes were higher than those of undetected genes (Fig. 2, right panel). A $\log _{2}$ signal intensity threshold of 98.3 was determined and only those genes with signal intensity smaller than 98.3 were filtered. 8985 genes were left for further analysis.

Of a total of about 30,000 probe sets, we observed that the expression of 701 genes (Table 3 ) were significantly different $(\mathrm{P}<0.001)$ between oocytes with poor developmental competence compared to normal one, 43 of which were altered $>1.2$-fold, and 13 of which $>1.5$-fold. Both up- or down-requlated genes are shown in Table 3. A Euclidean clustering of these differential genes is shown in Fig. 3. All four samples from poor oocyte developmental competence (PDC) group had similar gene expression patterns and were included in the same PDC cluster. On the other hand, all other four samples from normal oocyte developmental competence (NDC) group had similar gene expression patterns and were included in the same NDC 
Table 1 Summary on gene validation by RT-PCR in comparison with gene array results

\begin{tabular}{|c|c|c|c|c|c|c|}
\hline \multirow[t]{2}{*}{ Gene } & \multirow[t]{2}{*}{ Primer sequence } & \multirow[t]{2}{*}{ PCR product size (bp) } & \multirow[t]{2}{*}{ Location on rat chromosome } & \multirow[t]{2}{*}{ GenBank Access \# } & \multicolumn{2}{|c|}{$\begin{array}{c}\text { Fold changes (NDC/ } \\
\text { PDC) by }\end{array}$} \\
\hline & & & & & gene array & RT-PCR \\
\hline Lysyl oxidase & RV:AGTCTCTGACA & 129 & $18 q 11$ & NM_017061 & 2.8 & 2.86 \\
\hline \multirow[t]{3}{*}{$(L O X)$} & TCCGCCCTA C & & & & & \\
\hline & FW:ACCTGGTACCC & & & & & \\
\hline & GATCCCTA & & & & & \\
\hline Glycoprotein-4- & FW:AGATAAAGATG & 186 & $5 q 22$ & NM_053287 & -1.7 & -1.04 \\
\hline Beta-galactosyltrans & GGCGGCCGTTACT & & & & & \\
\hline ferase 2 (GGBT2; & RV:ACATGGTGTCT & & & & & \\
\hline UDP-Gal) & CCAGCCTGATTGA & & & & & \\
\hline Nerve growth factor & FW:AATGATGGGTT & 175 & Xq35 & NM_053401 & 1.6 & 1.03 \\
\hline receptor associated & GGGTGGAGATGGA & & & & & \\
\hline protein 1 (Ngfrap1; & RV:ACCGAAGTCAA & & & & & \\
\hline Bex3; Nade) & GGCATAAGGCAGA & & & & & \\
\hline \multirow{4}{*}{$\begin{array}{l}\text { Protein disulfide } \\
\text { isomerase- } \\
\text { associated } 5 \text { (Pdia5) }\end{array}$} & FW:ATATGACCGAG & 185 & $11 q 22$ & NM_001014125 & 1.8 & 1.86 \\
\hline & CTGTGACGCTGAA & & & & & \\
\hline & RV:ACATCTTTGGC & & & & & \\
\hline & TCCAGGGTCTTCT & & & & & \\
\hline \multirow{4}{*}{$\begin{array}{l}\text { Protein disulfide } \\
\text { isomerase- } \\
\text { associated } 6 \text { (Pdia6) }\end{array}$} & FW:ACCTTCTTTCT & 182 & Chromo- & NM_001004442 & 1.8 & 1.04 \\
\hline & AGCGGTCAGTGCT & & some 6 & & & \\
\hline & RV:AGTGCACTTGC & & & & & \\
\hline & TGCTTTCTTCCAC & & & & & \\
\hline \multirow{4}{*}{$\begin{array}{l}\text { Myeloid ecotropic } \\
\text { viral integration site } 1 \\
\text { homolog (Meis } 1 \text { ) }\end{array}$} & FW:TAGCCACCAAT & 99 & $14 q 22$ & XM_223643 & 1.6 & 1.33 \\
\hline & ATCATGAGGGCGT & & & & & \\
\hline & RV:TGAGTCCCGTA & & & & & \\
\hline & TCTTGTGCCAACT & & & & & \\
\hline \multirow[t]{4}{*}{ CD83 antigen } & FW:ATGTGCCTGAA & 193 & $17 p 12$ & NM_001108410 & 1.7 & 1.6 \\
\hline & TACCACCTGGACA & & & & & \\
\hline & RV:AGCCGCATGAA & & & & & \\
\hline & ACATGAAGCTGAC & & & & & \\
\hline \multirow[t]{4}{*}{ Lysozyme (Lyz) } & FW:TATGAACGCTG & 95 & $7 q 22$ & NM_012771 & 1.7 & 1.37 \\
\hline & TGAGTTCGCCAGA & & & & & \\
\hline & RV:TGCTGAGCTAA & & & & & \\
\hline & ACACACCCAGTCT & & & & & \\
\hline \multirow{4}{*}{$\begin{array}{l}\text { Trinucleotide repeat } \\
\text { containing } 6 \text { (Tnrc6) }\end{array}$} & FW:TGAAGTACCTC & 176 & $1 q 36$ & NM_001107549 & 1.7 & 1.03 \\
\hline & CACGATTCGCCA & & & & & \\
\hline & RV:TGCTGTTCTGC & & & & & \\
\hline & ACCTCTCCGTTAT & & & & & \\
\hline \multirow{4}{*}{$\begin{array}{l}\text { Interleukin } 13 \\
\text { receptor alpha } 1 \\
\text { (I/13ra1) }\end{array}$} & FW:AAGTGAGAAGC & 155 & $\mathrm{Xq12}$ & NM_145789 & 1.4 & 1.16 \\
\hline & CTAGCCCTTTGGT & & & & & \\
\hline & RV:AGTTGGTGTCC & & & & & \\
\hline & GGGCTTGTATTCT & & & & & \\
\hline \multirow[t]{4}{*}{$18 \mathrm{~S}$ rRNA } & FW:CGCGGTTCTAT & 219 & Chromo- & M11188 & Housekeeping & \\
\hline & TTTGTGGT & & some 3 & & & \\
\hline & RV:AGTCGGCATCG & & & & & \\
\hline & TTTATGGTC & & & & & \\
\hline
\end{tabular}


Table 2 In vitro fertilization and embryo transfer of oocytes from immature rats treated with eCG/anti-eCG/hCG

\begin{tabular}{|c|c|c|c|c|c|}
\hline $\begin{array}{l}\text { Experimental } \\
\text { Group }\end{array}$ & Rat & $\begin{array}{c}\text { Paired Ovarian weight } \\
(\mathrm{mg})\end{array}$ & $\begin{array}{l}\text { No (\%). of oocytes/ } \\
\text { fertilized }\end{array}$ & $\begin{array}{c}\text { No (\%). of pups/transferred } \\
\text { embryos }\end{array}$ & $\begin{array}{c}\text { No. of pups/ } \\
\text { implantation Sites }\end{array}$ \\
\hline \multirow[t]{5}{*}{ PDC } & A & 104.0 & & & \\
\hline & B & 109.8 & & & \\
\hline & C & 87.3 & 18/21(86) & $0 / 10(0)$ & $0 / 1$ \\
\hline & D & 131.6 & $36 / 37(97)$ & $0 / 9(0)$ & $0 / 2$ \\
\hline & Mean \pm SEM & $108.2 \pm 7.9$ & $(93.5 \pm 2.7)$ & (0) & $0 / 4 \pm 2$ \\
\hline \multirow[t]{5}{*}{ NDC } & $E$ & 98.7 & $23 / 23(100)$ & $4 / 10(40)$ & $4 / 6$ \\
\hline & $\mathrm{F}$ & 104.9 & 26/28(93) & $5 / 10(50)$ & $5 / 8$ \\
\hline & G & 79.9 & $12 / 12(100)$ & $3 / 10(30)$ & $3 / 4$ \\
\hline & $\mathrm{H}$ & 89.5 & 18/20(90) & $3 / 10(30)$ & $3 / 6$ \\
\hline & Mean \pm SEM & $93.3 \pm 4.7$ & $(95.8 \pm 2.2)$ & $(37.5 \pm 4.2)$ & $4 \pm 1 / 6 \pm 1$ \\
\hline
\end{tabular}

PDC: Oocytes with poor developmental competence; NDC: Oocytes with normal developmental competence.

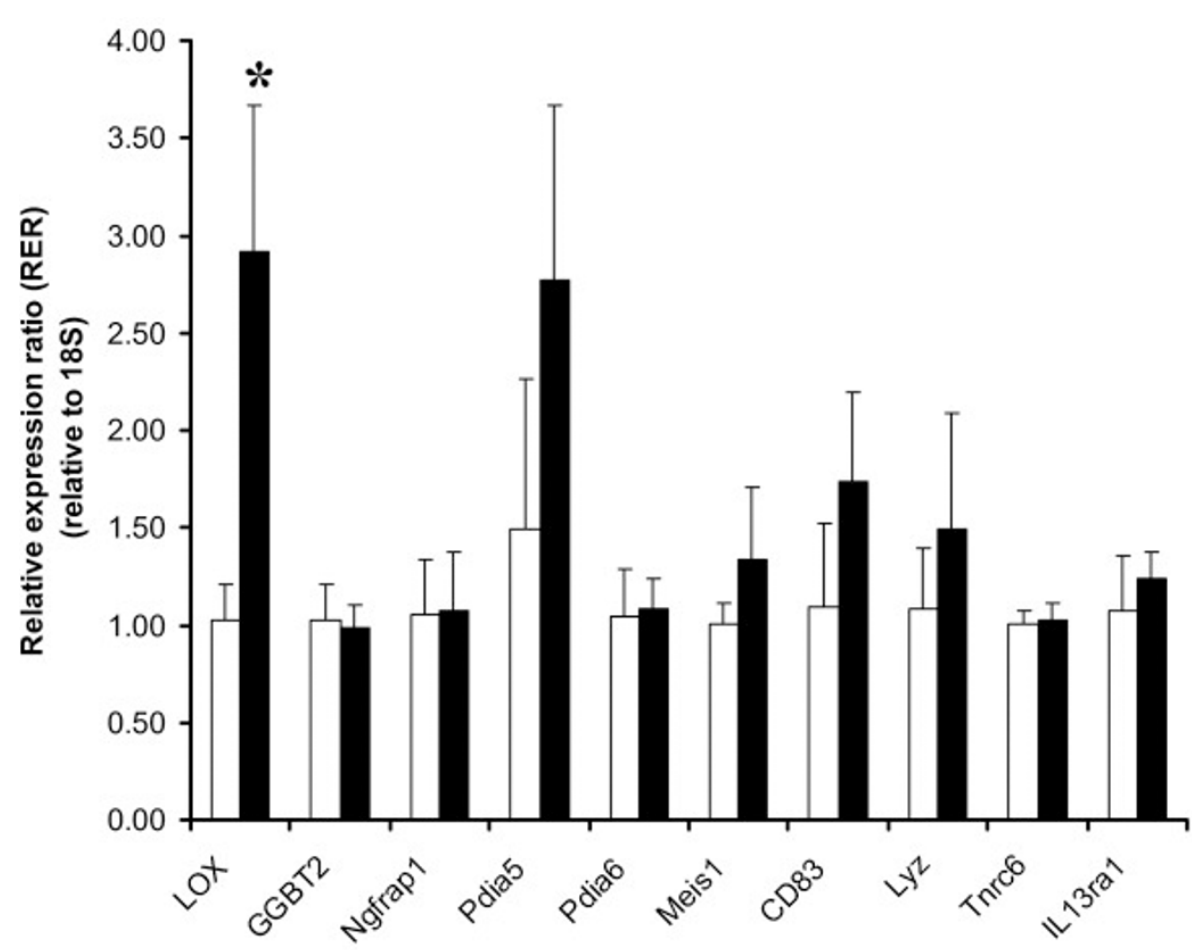

Figure 1 Validation of differentially expressed genes by real-time qPCR. Relative quantification of ten representative genes was performed. The method of Livak and Schmittgen (2001) was used to calculate the relative expression ratio (RER) that were normalized to a housekeeping gene 18S. Normal oocyte developmental competence (NDC) (solid bar) were expressed over poor oocyte developmental competence (PDC) (open bar), positive ratio refers to genes up-regulated, negative ratio indicated gene down-regulation, by which real-time qPCR data in the gene regulation trend (up- vs. down-regulation) were consistent with results obtained from microarray, of which the expression level of Lox (asterisk) was significantly higher in NDC in comparison to PDC $(P<0.05)$.

cluster. The gene expression patterns were very different between PDC and NDC clusters.

\section{Gene ontology analysis}

Gene ontology analysis showed that up-regulated genes in oocytes with normal developmental competence were linked to transcription regulation, protein phosphorylation and signal transduction, microtubule cytoskeleton organization and movement (Table 3 ). The genes participating in transcriptional regulation included nucleosome assembly protein 1-like 1, Necdin, Meis 1 and TAF9 RNA polymerase II and a transcribed locus 

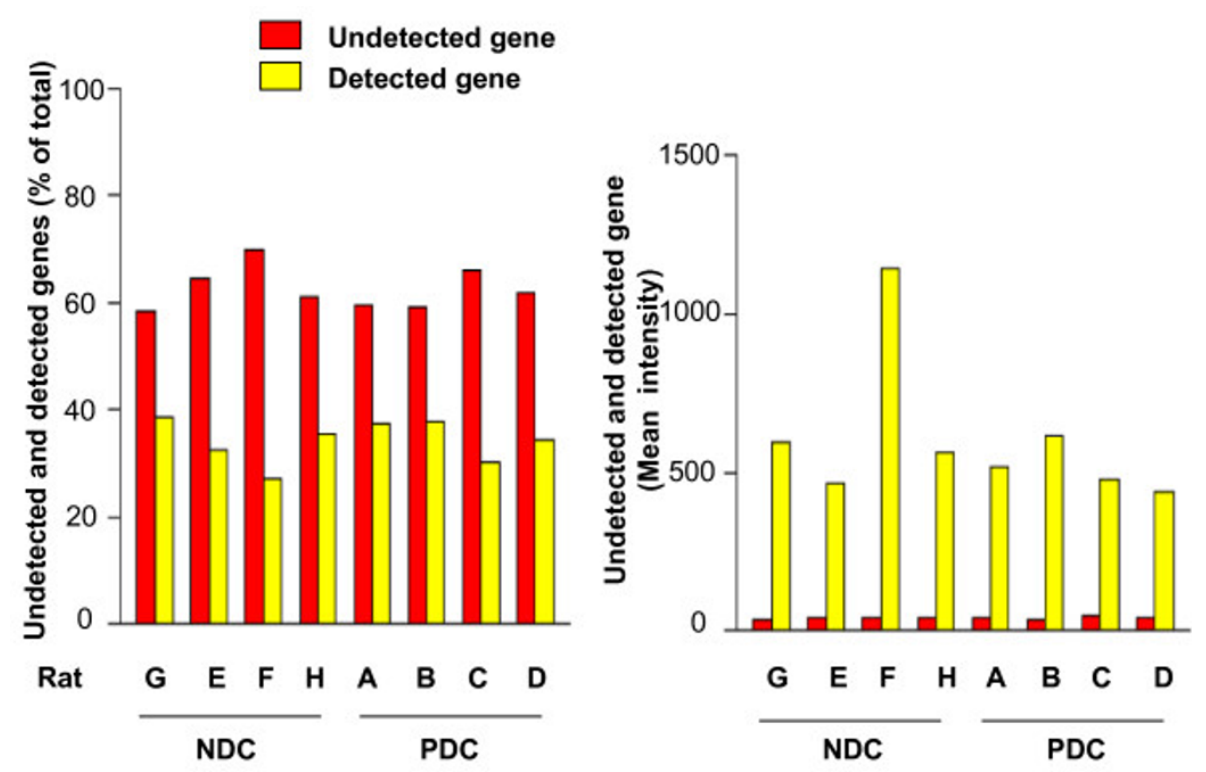

Figure 2 Percentages (left panel) and mean gene expression intensities (right panel) of detected and undetected genes in 8 gene arrays. The number of undetected genes was higher than that of detected genes in all arrays (left panel). However, the mean gene expression intensities of detected genes were much higher than those of undetected genes in all arrays (right panel).

homologous to polymerase I-transcript release factor $(P T R F)$, while those involved in the control of protein phosphorylation and signal transduction were Lox, Pdia 5 and Pdia6, golgi autoantigen and cell division cycle 2 -like 5 . The genes having a role in microtubule cytoskeleton organization and movement include CD83 antigen, Tnrc6, Goliath, vesicle-associated membrane protein 8 (Table 3).

Twelve genes were up-regulated, and one gene downregulated, more than 1.5 folds in NDC group than those in PDC group. Gene ontology classification showed that the up-regulated genes included Lox and Ngfrap1. Lox is important in the regulation of copper ion binding [30]. Ngfrap1 plays an important role in apoptosis induction [31]. The down-regulated gene is Ggbt2 known to be involved in the regulation of extracellular matrix organization and biogenesis [32].

\section{Identification of signaling pathways contributing to the normal oocyte developmental competence}

To determine the signaling pathways of up-regulated genes associated with normal oocyte developmental competence, all genes with more than 1.2-fold change were subjected to the pathway analysis by Pathwayexplorer https://pathwayexplorer.genome.tugraz.at/. Although no directly related pathways were found, a potential signaling pathway of the highest-regulated gene, Lox, could be envisaged since oocyte-derived factors such as GDF-9 increases gene expression of Lox which induces differentiation of mural granulosa cells [33].
Quantitative real-time PCR validation of microarray data Ten representative genes, the expression levels of which were remarkably changed in microarray (Table 3), were selected for further validation by RT-PCR analyses. Of ten genes selected, Lox, Pdia5, and CD83 antigen mRNA abundance of mural granulosa cells in normal oocyte developmental competence group were higher (fold changes $>1.6$ ) than that in poor oocyte developmental competence group, consistently in both gene microarray and quantitative RT-PCR analyses. The fold change from microarray and that from RT-PCR exhibit excellent concordance, with Pearson correlation equal to 0.94 ( $\mathrm{p}<0.0001$ ). However, only Lox was statistically significantly different between the two groups (fold changes $>2.8, \mathrm{P}<0.05$, Fig. 1 and Table 1). Our data suggested that the profile of Lox gene in mural granulosa cells could be a likely candidate for a potential biomarker for follicular maturity and oocyte quality.

\section{Discussion}

In the present study, using whole genome gene expression profiling of mural granulosa cells, we have demonstrated that mural granulosa cells isolated from follicles containing oocytes with normal developmental competence are distinct from those with oocytes exhibiting poor developmental competence. The dissimilarity between these two groups was clearly shown through unsupervised hierarchical clustering of these samples and was substantiated using binary tree prediction as well as expression data from independent arrays. The 
Table 3 Expression and their biological functions of genes in mural granulosa cells of follicles containing oocyte with normal developmental competence compared to those with poor developmental competence, as determined by Gene Ontology Analysis

\begin{tabular}{|c|c|c|c|}
\hline $\begin{array}{l}\text { Probe } \\
\text { position at } \\
\text { array }\end{array}$ & $\begin{array}{c}\text { Fold } \\
\text { changes* }\end{array}$ & Gene & Biological functions \\
\hline \multicolumn{4}{|c|}{ Transcription regulation genes } \\
\hline 1367847 & 1.8 & Nuclear protein 1 & Unknown \\
\hline 1384308 & 1.6 & $\begin{array}{l}\text { Meis1 (myeloid ecotropic viral } \\
\text { integration site } 1 \text { homolog) }\end{array}$ & Regulation of transcription, DNA dependent \\
\hline 1371947 & 1.6 & Necdin & Unknown \\
\hline 1371822 & 1.5 & $\begin{array}{l}\text { RNA polymerase III (DNA directed) } \\
\text { polypeptide D }\end{array}$ & Regulation of progression through cell cycle \\
\hline 1375414 & 1.5 & $\begin{array}{l}\text { TAF9 RNA polymerase II [TATA box } \\
\text { binding protein (TBP)-associated factor] }\end{array}$ & Negative regulation of transcription from RNA polymerase II promoter \\
\hline 1390116 & 1.4 & $\begin{array}{l}\text { Transcribed locus: similar to polymerase } \\
\text { l-transcript release factor (PTRF) }\end{array}$ & Unknown \\
\hline 1374780 & 1.3 & Transcribed locus & Unknown \\
\hline 1372093 & 1.3 & Max interacting protein 1 & Unknown \\
\hline 1373978 & 1.3 & $\begin{array}{l}\text { Nuclear cap binding protein subunit } 1 \\
(80 \mathrm{kDa})\end{array}$ & RNA splicing and Mrna cleavage \\
\hline 1385486 & 1.3 & Transcribed locus & Unknown \\
\hline 1380827 & 1.3 & Similar to C1orf25 & tRNA processing \\
\hline 1370826 & 1.3 & Nucleosome assembly protein 1-like 1 & $\begin{array}{l}\text { DNA replication, nucleosome assembly and positive regulation of cell } \\
\text { proliferation }\end{array}$ \\
\hline 1376597 & 1.3 & $\begin{array}{l}\text { Ninc finger, } \mathrm{CCHC} \text { domain containing } \\
10\end{array}$ & Unknown \\
\hline $1388067 a$ & -1.3 & $\begin{array}{l}\text { Glucocorticoid modulatory element } \\
\text { binding protein } 2\end{array}$ & Regulation of transcription, transcription from RNA polymerase II promoter \\
\hline \multicolumn{4}{|c|}{ Post-translation regulation genes } \\
\hline 1368171 & 2.8 & Lysyl oxidase & $\begin{array}{l}\text { Protein modification, copper ion binding oxidoreductase activity, cancer } \\
\text { metastasis, granulosa cell differentiation }\end{array}$ \\
\hline 1374828 & 1.8 & Protein disulfide isomerase-associated 5 & Electron transport, protein folding and response to stress \\
\hline 1370859 & 1.5 & Protein disulfide isomerase associated 6 & Electron transport, protein folding and electron transport \\
\hline 1398895 & 1.4 & Golgi autoantigen, golgin subfamily a,7 & Protein amino acid palmitoylation \\
\hline 1392149 & 1.3 & Transcribed locus & Unknown \\
\hline $1368653 a$ & 1.3 & $\begin{array}{l}\text { Parkinson disease (autosomal recessive, } \\
\text { early onset) } 7\end{array}$ & Protein folding, cell proliferation and adult locomotory behavior \\
\hline $1387258 a$ & 1.3 & $\begin{array}{l}\text { Protein-L-isoaspartate (D-aspartate) } \mathrm{O} \text { - } \\
\text { methyltransferase } 1\end{array}$ & $\begin{array}{l}\text { Protein methylation, S-adenosylhomocysteine metabolism and protein } \\
\text { modification }\end{array}$ \\
\hline 1386164 & 1.3 & $\begin{array}{l}\text { Cell division cycle 2-like } 5 \\
\text { (cholinesterase-related cell division } \\
\text { controller) }\end{array}$ & $\begin{array}{l}\text { Protein phosphorylation, regulation of mitosis and positive regulation of cell } \\
\text { proliferation }\end{array}$ \\
\hline 1398343 & 1.2 & $\begin{array}{l}\text { DNAJ (Hsp40) homolog, subfamily A, } \\
\text { member } 4\end{array}$ & Protein folding \\
\hline 1383475 & -1.3 & $\begin{array}{l}\text { Protein phosphatase } 1 \mathrm{~A} \text {, magnesium } \\
\text { dependent, alpha isoform }\end{array}$ & Protein dephosphorylation, positive regulation of IkB kinase/NFkB cascade \\
\hline \multicolumn{4}{|c|}{ Microtubule cytoskeleton regulation genes } \\
\hline 1370154 & 1.7 & Lysozyme & Antimicrobial activity in human follicular fluid, ovulation \\
\hline 1390529 & 1.7 & CD83 antigen & Defense response, humoral immune response and signal transduction \\
\hline 1375664 & 1.7 & Trinucleotide repeat containing 6 & Microtubule-based movement \\
\hline 1369948 & 1.6 & $\begin{array}{l}\text { Nerve growth factor receptor associated } \\
\text { protein } 1\end{array}$ & Induction of apoptosis, increase in PCO ovaries \\
\hline 1374321 & 1.4 & Similar to RIKEN cDNA 2700081015 & Unknown \\
\hline 1388711 & 1.4 & Interleukin 13 receptor, alpha 1 & Cell surface receptor linked signal transduction \\
\hline 1372330 & 1.4 & Goliath & Apoptosis and proteolysis \\
\hline 1372682 & 1.3 & Similar to RIKEN cDNA 2810432L12 & Unknown \\
\hline
\end{tabular}


Table 3: Expression and their biological functions of genes in mural granulosa cells of follicles containing oocyte with normal developmental competence compared to those with poor developmental competence, as determined by Gene Ontology Analysis (Continued)

\begin{tabular}{|c|c|c|c|}
\hline 1372093 & 1.3 & Max interacting protein 1 & Unknown \\
\hline $1386952 a$ & 1.3 & $\begin{array}{l}\text { Dynein, cytoplasmic, intermediate chain } \\
2\end{array}$ & Microtubule-based movement \\
\hline 1380577 & 1.3 & $\begin{array}{l}\text { ATP-binding cassette, sub-family } G \\
\text { (WHITE), member } 2\end{array}$ & Drug transport \\
\hline 1369970 & 1.3 & Vesicle-associated membrane protein 8 & Protein complex assembly and vesicle-mediated transport \\
\hline 1367716 & 1.2 & T-cell immunomodulatory protein & Unknown \\
\hline 1373090 & 1.2 & Signal sequence receptor, alpha & $\begin{array}{l}\text { Cotranslational protein targeting to membrane, positive regulation of cell } \\
\text { proliferation }\end{array}$ \\
\hline $1376874 a$ & 1.2 & $\begin{array}{l}\text { Adaptor-related protein complex AP-4, } \\
\text { beta } 1\end{array}$ & Intracellular protein transport, vesicle-mediated transport \\
\hline 1383206 & 1.2 & $\begin{array}{l}\text { Component of oligomeric golgi } \\
\text { complex } 3\end{array}$ & Intracellular protein transport \\
\hline 1369549 & -1.3 & $\begin{array}{l}\text { Killer cell lectin-like receptor subfamily K, } \\
\text { member } 1\end{array}$ & Unknown \\
\hline 1371073 & -1.7 & $\begin{array}{l}\text { UDP-Gal: betaGlcNAc beta 1,4- } \\
\text { galactosyltransferase, ploypeptide } 1\end{array}$ & $\begin{array}{l}\text { Promote apoptosis, } \mathrm{N} \text {-acetyllactosaminesynthase activity, beta-N-acetylgluco- } \\
\text { saminylglycopeptide beta-1,4-galactosyltransferase activity, carbohydrate } \\
\text { metabolism, development of secondary sexual characteristics, extracellular } \\
\text { matrix organization and biogenesis, galactose metabolism, integral to } \\
\text { membrane, lactose synthase activity, oligosaccharide biosynthesis, transferase } \\
\text { activity, }\end{array}$ \\
\hline
\end{tabular}

*Fold changes represent difference of gene expression in granulosa cells from follicles containing oocytes with normal developmental competence compared with that with poor developmental competence. "-": down-regulation; others: up-regulation

identification of two unique branches containing normal and poor oocyte developmental competence is consistent with the distinct developmental outcome after embryo transfer. Meanwhile, our comparison of gene expression profiles between different samples within the same group showed that there was a high "withingroup" similarity, demonstrating the quality of our gene expression experiment. Differentially expressed genes in these two groups might be further tested as potential biomarkers of oocyte quality, in particular the highest changed gene encoding lysyl oxidase that plays an important role in the regulation of differentiation of mural granulosa cells.

The assessment of differential gene expression between two groups, in conjunction with gene ontogeny analysis, showed that differences in genes were associated with regulation of transcription and DNA replication and cell cycle progression, protein folding, phosphorylation and signaling pathways, microtubule cytoskeleton organization and movement, and receptor signaling and apoptosis. Of principal importance was the gene "Lox" which, with the largest difference in expression, has been shown to be involved in the regulation of mural granulosa cell differentiation. Lox was expressed 2.8-fold higher in mural granulosa cells in follicles producing normal oocyte than poor oocyte developmental competence. This enzyme oxidizes peptidyl lysine to peptidyl aldehyde residues within collagen and elastin, initiating formation of the covalent cross- linkages that insolubilize these extracellular proteins [34]. This enzyme is also present and active within rat vascular smooth muscular cell nuclei, exhibits its catalytic activity on histone $\mathrm{H} 1[35,36]$, suggesting that it may regulate chromatin remodeling involved in the regulation of transcription [37]. It has been shown that Lox is expressed in cultured bovine granulosa cells and involved in the maintenance of cell differentiation [30]. The activity of this enzyme is increased in rabbit ovarian follicles after hCG-induced ovulation and its mRNA expression is up-regulated at the time of ovulation in perch ovary $[38,39]$. However, rat granulosa cell Lox transcripts were significantly suppressed $48 \mathrm{~h}$ after eCG injection compared with untreated controls and were further reduced during hCG-induced luteinization [38]. Furthermore, FSH dose-dependently inhibited Lox mRNA and enzyme activity in cultured rat granulosa cells [33].

In the present study, Lox mRNA abundance was 2.8-fold higher in mural granulosa cells isolated from follicles containing oocytes which exhibit normal developmental competence when compared with poor ones. This result was validated by real-time PCR. It has been demonstrated that TGF $\beta 1$ and GDF9 increase Lox mRNA expression in human lung fibroblasts [40] and rat granulosa cells [33], respectively. Since the actions of TGF $\beta$ superfamily members are mediated via the Smad2/Smad3 pathways [33], these findings raise the interesting possibility that the GDF9-induced preantral 


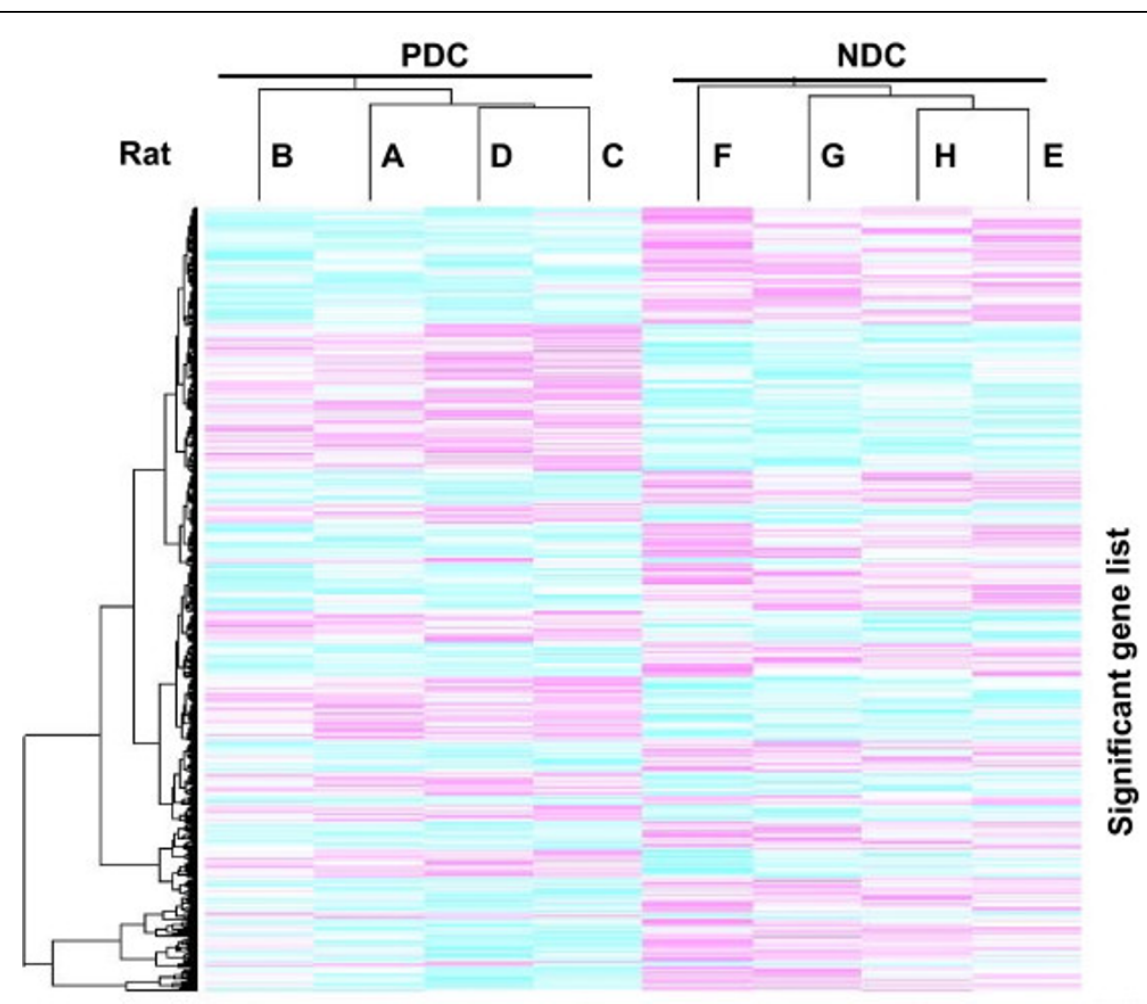

Figure 3 Unsupervised hierarchical clustering analysis of $\mathbf{7 0 1}$ differentially expressed probe sets in all arrays. To identify the relationships between samples, a 1 - correlation metric with centroid linkage was applied to those probe sets. A dendrogram containing two distinct arms was identified. All four samples from poor oocyte developmental competence (PDC) group had similar gene expression patterns and were included in the same PDC cluster. On the other hand, all other four samples from normal oocyte developmental competence (NDC) group had similar gene expression patterns and were included in the same NDC cluster. The gene expression patterns were very different between PDC and NDC clusters.

follicular growth in vitro [12] involves increased mural granulosa cell Lox mRNA expression. Whether this indeed is the case awaits further investigation.

In addition to Lox, Pdia5 is also up-regulated at less extent in the normal oocyte developmental competence group. Although Pdia5 plays an important role in the regulation of electron transport, protein folding and stress response [41], posttranslational protein modification and is essential for normal cell function [42], the differences between the two experimental groups are not statistically significant as determined by real-time PCR. The physiological significance of this observation remains unclear.

\section{Conclusions}

The present studies demonstrate a close association between the expression of Lox in mural granulosa cells and the developmental competence of oocytes. These findings suggest that the most diffentially expressed gene, lysyl oxidase, may be a potential biomarker for oocyte health in assisted reproduction. Further studies are required to confirm this notion.

\section{Funding}

This work was supported in part by a grant from the Canadian Institutes of Health Research (MOP-10369) and by the World Class University (WCU) program (R31-10056) through the National Research Foundation of Korea funded by the Ministry of Education, Science and Technology. In addition, the studies described were part of the Program on Oocyte Health http://www.ohri. ca/oocyte funded under the Healthy Gametes and Great Embryos Strategic Initiative of the Canadian Institutes of Health Research (CIHR) Institute of Human Development, Child and Youth Health (IHDCYH), grant number HGG62293. J.Y.J. and M.C. are recipients of CIHR-STIRRHS Postdoctoral Fellowships.

\section{Acknowledgements}

The authors thank staff in Animal Care Services at Ottawa Hospital Research Institute for the maintenance and care of the animals used.

\section{Author details}

${ }^{1}$ Department of Obstetrics \& Gynecology and Cellular \& Molecular Medicine, University of Ottawa, Ottawa Hospital Research Institute, Ottawa, ON K1Y 4E9, Canada. ${ }^{2}$ Department of Biology and Center for Advanced Research in 
Environmental Genomics, University of Ottawa, Ottawa, ON K1N 6N5, Canada. ${ }^{3}$ Centre de Recherche en Biologie de la Reproduction, Département de Sciences Animales, Université Laval, Ste-Foy, QuébecG1K 7P4, Canada. ${ }^{4}$ WCU Biomodulation Major, Department of Agricultural Biotechnology, Seoul National University, Seoul 151-921, Korea.

\section{Authors' contributions}

JYJ designed the experiment, conducted animal studies (including development and injection of eCG-antibody, IVF/embryo transfer and collection of cells), extracted RNA and prepared manuscript. HX analyzed gene array data and was assisted by XX. MC performed real-time RT-PCR. MAS assisted in experimental design. BKT involved in designing this study and developing the manuscript. All authors have read and approved the final manuscript

\section{Competing interests}

The authors declare that they have no competing interests.

Received: 3 January 2010 Accepted: 6 March 2010

Published: 6 March 2010

\section{References}

1. Eppig JJ: Oocyte control of ovarian follicular development and function in mammals. Reproduction 2001, 122:829-838.

2. Carabatsos MJ, Sellitto C, Goodenough DA, Albertini DF: Oocyte-granulosa cell heterologous gap junctions are required for the coordination of nuclear and cytoplasmic meiotic competence. Dev Biol 2000, 226:167-179.

3. Brower PT, Schultz RM: Intercellular communication between granulosa cells and mouse oocytes: existence and possible nutritional role during oocyte growth. Dev Biol 1982, 90:144-153.

4. Thomas FH, Vanderhyden BC: Oocyte-granulosa cell interactions during mouse follicular development: regulation of kit ligand expression and its role in oocyte growth. Reprod Biol Endocrinol 2006, 4:19.

5. Chesnel F, Wigglesworth K, Eppig JJ: Acquisition of meiotic competence by denuded mouse oocytes: participation of somatic-cell product(s) and cAMP. Dev Biol 1994, 161:285-295.

6. de la Fuente R, Eppig JJ: Transcriptional activity of the mouse oocyte genome: companion granulosa cells modulate transcription and chromatin remodeling. Dev Biol 2001, 229:224-236.

7. Matzuk MM, Burns KH, Viveiros MM, Eppig Jj: Intercellular communication in the mammalian ovary: oocytes carry the conversation. Science 2002, 296:2178-2180.

8. Vanderhyden BC, Telfer EE, Eppig JJ: Mouse oocytes promote proliferation of granulosa cells from preantral and antral follicles in vitro. Biol Reprod 1992, 46:1196-204.

9. Vanderhyden BC, Caron PJ, Buccione R, Eppig JJ: Developmental pattern of the secretion of cumulus expansion-enabling factor by mouse oocytes and the role of oocytes in promoting granulosa cell differentiation. Dev Biol 1990, 140:307-17.

10. Buccione R, Vanderhyden BC, Caron PJ, Eppig JJ: FSH-induced expansion of the mouse cumulus oophorus in vitro is dependent upon a specific factor(s) secreted by the oocyte. Dev Biol 1990, 138:16-25.

11. Otsuka F, Yamamoto S, Erickson GF, Shimasaki S: Bone morphogenetic protein-15 inhibits follicle-stimulating hormone (FSH) action by suppressing FSH receptor expression. J Biol Chem 2001, 276:11387-92.

12. Orisaka M, Orisaka S, Jiang JY, Craig J, Wang Y, Kotsuji F, et al: Growth differentiation factor 9 is antiapoptotic during follicular development from preantral to early antral stage. Mol Endocrinol 2006, 20:2456-2468.

13. Hunter MG, Brankin V, Quinn RL, Ferguson EM, Edwards SA, Ashworth CJ: Oocyte-somatic cell-endocrine interactions in pigs. Domest Anim Endocrinol 2005, 29:371-384.

14. McKenzie LJ, Pangas SA, Carson SA, Kovanci E, Cisneros P, Buster JE, et al: Human cumulus granulosa cell gene expression: a predictor of fertilization and embryo selection in women undergoing IVF. Hum Reprod 2004, 19:2869-2874.

15. Rhodes TL, McCoy TP, Higdon HL III, Boone WR: Factors affecting assisted reproductive technology (ART) pregnancy rates: a multivariate analysis. $J$ Assist Reprod Genet 2005, 22:335-346.

16. Racowsky C: High rates of embryonic loss, yet high incidence of multiple births in human ART: is this paradoxical? Theriogenology 2002, 57:87-96.
17. Jiang JY, Umezu M, Sato E: Improvement of follicular development rather than gonadotrophin secretion by thyroxine treatment in infertile immature hypothyroid rdw rats. J Reprod Fertil 2000, 119:193-199.

18. Jiang JY, Miyoshi K, Umezu M, Sato E: Superovulation of immature hypothyroid rdw rats by thyroxine therapy and the development of eggs after in vitro fertilization. J Reprod Fertil 1999, 116:19-24.

19. Mihm M, Baker PJ, Ireland JL, Smith GW, Coussens PM, Evans AC, et al Molecular evidence that growth of dominant follicles involves a reduction in follicle-stimulating hormone dependence and an increase in luteinizing hormone dependence in cattle. Biol Reprod 2006, 74:1051-1059.

20. Boone DL, Carnegie JA, Rippstein PU, Tsang BK: Induction of apoptosis in equine chorionic gonadotropin (eCG)-primed rat ovaries by anti-eCG antibody. Biol Reprod 1997, 57:420-427.

21. Kim JM, Boone DL, Auyeung A, Tsang BK: Granulosa cell apoptosis induced at the penultimate stage of follicular development is associated with increased levels of Fas and Fas ligand in the rat ovary. Biol Reprod 1998, 58:1170-6.

22. Wang $H$, Jiang JY, Zhu C, Peng C, Tsang BK: Role and regulation of nodal/ activin receptor-like kinase 7 signaling pathway in the control of ovarian follicular atresia. Mol Endocrinol 2006, 20:2469-2482.

23. Jiang JY, Tsang BK: Optimal conditions for successful in vitro fertilization and subsequent embryonic development in Sprague-Dawley rats. Biol Reprod 2004, 71:1974-1979.

24. Bolstad BM, Irizarry RA, Astrand M, Speed TP: A comparison of normalization methods for high density oligonucleotide array data based on variance and bias. Bioinformatics 2003, 19:185-193.

25. Irizarry RA, Bolstad BM, Collin F, Cope LM, Hobbs B, Speed TP: Summaries of Affymetrix GeneChip probe level data. Nucleic Acids Res 2003, 31:e15.

26. Pelizzola M, Pavelka N, Foti M, Ricciardi-Castagnoli P: AMDA: an R package for the automated microarray data analysis. BMC Bioinformatics 2006, 7:335.

27. Saeed Al, Sharov V, White J, Li J, Liang W, Bhagabati N, et al: TM4: a free, open-source system for microarray data management and analysis. Biotechniques 2003, 34:374-378.

28. Dennis G Jr, Sherman BT, Hosack DA, Yang J, Gao W, Lane HC, et al: DAVID: Database for Annotation, Visualization, and Integrated Discovery. Genome Biol 2003, 4:3.

29. Livak KJ, Schmittgen TD: Analysis of relative gene expression data using real-time quantitative PCR and the 2(-Delta Delta $C(T))$ Method. Methods 2001, 25:402-408.

30. Kendall NR, Marsters P, Scaramuzzi RJ, Campbell BK: Expression of lysyl oxidase and effect of copper chloride and ammonium tetrathiomolybdate on bovine ovarian follicle granulosa cells cultured in serum-free media. Reproduction 2003, 125:657-665.

31. Nocentini G, Giunchi L, Ronchetti S, Krausz LT, Bartoli A, Moraca R, et al: A new member of the tumor necrosis factor/nerve growth factor receptor family inhibits T cell receptor-induced apoptosis. Proc Natl Acad Sci USA 1997, 94:6216-6221.

32. Asano M, Furukawa K, Kido M, Matsumoto S, Umesaki $Y$, Kochibe $N$, et al: Growth retardation and early death of beta-1,4-galactosyltransferase knockout mice with augmented proliferation and abnormal differentiation of epithelial cells. EMBO J 1997, 16:1850-1857.

33. Harlow CR, Rae M, Davidson L, Trackman PC, Hillier SG: Lysyl oxidase gene expression and enzyme activity in the rat ovary: regulation by folliclestimulating hormone, androgen, and transforming growth factor-beta superfamily members in vitro. Endocrinology 2003, 144:154-162.

34. Li W, Nellaiappan K, Strassmaier T, Graham L, Thomas KM, Kagan HM: Localization and activity of lysyl oxidase within nuclei of fibrogenic cells. Proc Natl Acad Sci USA 1997, 94:12817-12822.

35. Kagan HM, Li W: Lysyl oxidase: properties, specificity, and biological roles inside and outside of the cell. J Cell Biochem 2003, 88:660-672.

36. Mello ML, Contente S, Vidal BC, Planding W, Schenck U: Modulation of ras transformation affecting chromatin supraorganization as assessed by image analysis. Exp Cell Res 1995, 220:374-382.

37. Grattarola M, Borghi C, Emionite L, Lulli P, Chessa L, Vergani L: Modifications of nuclear architecture and chromatin organization in ataxia telangiectasia cells are coupled to changes of gene transcription. J Cell Biochem 2006, 99:1148-1164.

38. Slee RB, Hillier SG, Largue P, Harlow CR, Miele G, Clinton M: Differentiationdependent expression of connective tissue growth factor and lysyl 
oxidase messenger ribonucleic acids in rat granulosa cells. Endocrinology 2001, 142:1082-1089

39. Langenau DM, Goetz FW, Roberts SB: The upregulation of messenger ribonucleic acids during 17alpha, 20beta-dihydroxy-4-pregnen-3-oneinduced ovulation in the perch ovary. J Mol Endocrinol 1999, 23:137-152.

40. Roy R, Polgar P, Wang Y, Goldstein RH, Taylor L, Kagan HM: Regulation of lysyl oxidase and cyclooxygenase expression in human lung fibroblasts: interactions among TGF-beta, IL-1 beta, and prostaglandin E. J Cell Biochem 1996, 62:411-417.

41. Turano C, Coppari S, Altieri F, Ferraro A: Proteins of the PDI family: unpredicted non-ER locations and functions. J Cell Physiol 2002, 193:154-163.

42. Knizetova P, Vancova I, Kocakova P, Slovak M, Proost P, Kopacek J: New member of the protein disulfide isomerase (PDI) family identified in Amblyomma variegatum tick. Insect Biochem Mol Biol 2006, 36:943-953.

doi:10.1186/1757-2215-3-6

Cite this article as: Jiang et al: Mural granulosa cell gene expression associated with oocyte developmental competence. Journal of Ovarian Research 2010 3:6.

\section{Submit your next manuscript to BioMed Central and take full advantage of:}

- Convenient online submission

- Thorough peer review

- No space constraints or color figure charges

- Immediate publication on acceptance

- Inclusion in PubMed, CAS, Scopus and Google Scholar

- Research which is freely available for redistribution

Submit your manuscript at www.biomedcentral.com/submit 